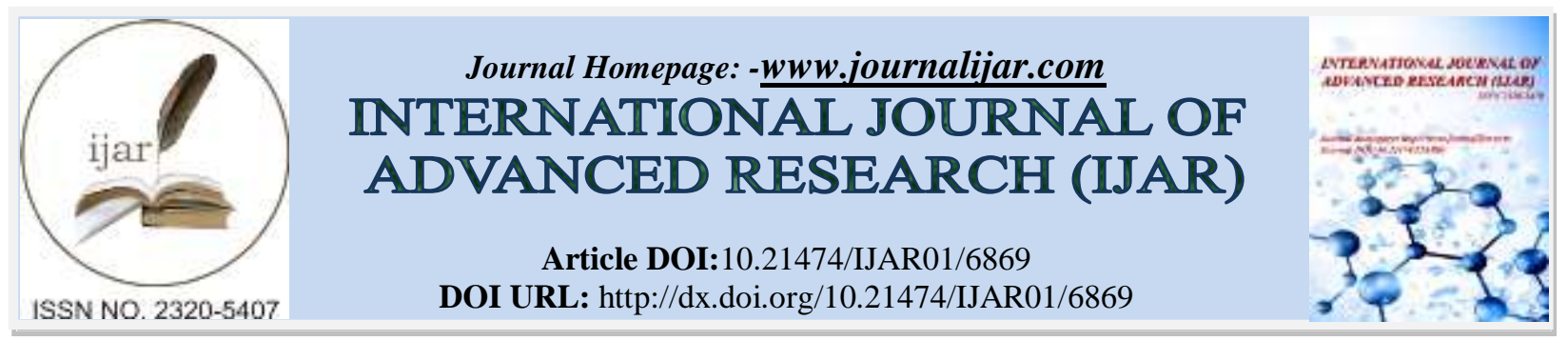

RESEARCH ARTICLE

\title{
THE DEVELOPMENT OF PROBLEM BASED LEARNING WORKSHEET TO TRAIN STUDENT CRITICAL THINKING SKILLS ON WORKS AND ENERGY MATERIALS.
}

\author{
Hamatun, Agus Suyatna, Undang Rosidin and Chandra Ertikanto. \\ ${ }^{1}$ Graduate Program of Physics Education, Lampung University, Indonesia.
}

\section{Manuscript Info}

Manuscript History

Received: 07 February 2018

Final Accepted: 09 March 2018

Published: April 2018

Keywords:

Problem based learning, worksheet,

Critical thinking skills

\begin{abstract}
Student's Worksheet (SW) can help students to find a concept independently by solving every problem in it. To get SW that is suit to the needs, then in developing the SW it is needed to be combined with a learning model in accordance with student's needs. One of learning models that can be utilized is Problem Based Learning (PBL). The PBL model is one of learning models that can train students' critical thinking skills. The purpose of this research is to develop SW based on PBL to train students' critical thinking skill. Research method of this paper is Research and Development which contains seven research steps: information collection, planning, initial product draft development, product testing (validation), product revision, field trial, and final products. Product validation includes content validity, construct validity, and legibility using questionnaires. Average score of content validity is categorized as excellent, construct validity as good, and legibility of the product as excellent category. So, it can be stated that $\mathrm{SW}$ is feasible to be used in the learning process. Moreover, teacher response result is categorized as excellent and students' response results good. The result of effectiveness test shows that post test score average is higher than pretest score average, and then experimental ngain class score is higher than control class. Students' critical thinking skills also improved in every indicator of critical thinking. Thus, it can be concluded that SW based on PBL as developed product of this research is effective in training students' critical thinking skill.
\end{abstract}

Copy Right, IJAR, 2018,. All rights reserved.

\section{Introduction:-}

Minister of Education and Culture number 69 year 2013 about the Basic Framework and Structure of Curriculum Senior High School (SHS) states that the 2013 curriculum is developed with a refinement of mindset, that are; teacher-centered learning becomes student-centered learning, passive learning becomes active learning.

In general, teacher's current learning is still teacher-centered. This is based on preliminary research at SHS State 10 Bandar Lampung where in learning activities students are not given an opportunity to conclude findings of the given problem. Preliminary research was conducted by filling questionnaires by teachers and students. 
In learning activities in a school, to make students actively involve and able to obtain their knowledge independently, it is needed a learning resource that can minimize role of teacher and add students' activeness. Learning using SW can make students become more active and efficient in learning activity (Lee, 2014).

SW can be used by students to find a concept independently by solving every problem in it. SW also provides a variety of questions so as to enhance students' experiences to solve problems, both in relation to daily life and abstract issues. To get the SW that suit the needs, then in developing SW it is needed to be combined with learning model in accordance with students' needs. (Fitriani et al., 2017) SW is part of teaching aids intended to facilitate teaching and learning activities and to make it easier to understand the concepts of learning.

One of the learning models that can be utilized is PBL. According to Ward and Lee (2002) PBL model is a learning model that involves students to solve a problem through the stages of scientific method so that students can learn the knowledge related to the problem and also have skills to solve problems. The stages of scientific method in PBL model presented in SW can guide students into independent learners and it is directly involved actively in group of learning. Learning using PBL model can improve learning activities, problem-solving skills, and develop nature or character of students (Raimi and Adeoye, 2012). Through PBL learning model, students will be trained in handling problems and trained to find alternative ways of solving problems.

Physics subjects, learning about phenomena of nature systematically, are subjects that can be a means to educate students to practice critical thinking skills. This is in line with the results of a research done by Lien (2009) which states that learning PBL can improve ability of critical thinking and self-learning skills of students.

Based on questionnaire, student and teacher needs analysis in SHS State 10 Bandar Lampung shows that students do not use SW as a learning medium, but instructional media used in the school are printed books containing only materials and practice questions. From result of questionnaire of requirement analysis, $100 \%$ of teachers agree if learning media in form of based on PBL is expected to help training students' critical thinking skill. While questionnaire results of student needs analysis, $86.67 \%$ agree to have learning media in form of SW. Therefore, it is necessary to develop SW based on PBL Works and Energy subjects to train students' critical thinking skills.

\section{Methods:-}

Ten steps developed by Gall, et al, in this study the steps that are implemented only step one to step seven. This is because some limitations, both in terms of time and cost. The research method used is research development (Research and Development). The procedure used is the procedure Gall, et al (2003). This procedure includes ten steps, namely (1) information gathering, (2) planning; (3) development of initial product draft; (4) product testing (validation); (5) product revision; (6) field trial; (7) revision of operational product, (8) operational product trial; (9) final product revision; and (10) dissemination and implementation.

The data collected comes from expert test contents and design, questionnaires, as well as special tests. Expert and design tests were conducted by two expert lecturers and an expert practitioner, while questionnaire and special tests were given to 25 students of class X SHS State 10 Bandar Lampung as an experimental class. Questionnaires are used to determine response of teachers and students about products that have been developed. While special tests of pretest and posttest are used to determine product effectiveness.

Data analysis based on expert instrument is done to know validity and feasibility of product that has been developed based on test instrument that has been made. In the questionnaire instrument of expert validation test assessment, product assessment by validator is done by giving assessment on aspect with score 1-5 using Likert Scale as guidance (Haryati, 2007). It can be seen as follows:

Table 1:-Score assessment of answer choice guidance

\begin{tabular}{|l|l|}
\hline Category & Score \\
\hline Excellent & 5 \\
\hline Good & 4 \\
\hline Fair & 3 \\
\hline Poor & 2 \\
\hline Very Poor & 1 \\
\hline
\end{tabular}


Experiment validation test results are then converted to qualitative scores on Likert Scale based on the following criteria. (Haryati, 2007)

Table 2: Conversion of quantitative data to qualitative data with Likert Scale

\begin{tabular}{|l|l|}
\hline Score Range & Qualitative Criteria \\
\hline$X>\bar{X}+1,80 S B I$ & Excellent \\
\hline $\bar{X}+0,60 S B I<X \leq \bar{X}+1,80 S B I$ & Good \\
\hline $\bar{X}-0,60 S B I<X \leq \bar{X}+0,60 S B I$ & Fair \\
\hline $\bar{X}-1,80 S B I<X \leq \bar{X}-0,60 S B I$ & Poor \\
\hline$X>\bar{X}-1,80 S B I$ & Very Poor \\
\hline
\end{tabular}

(Widoyoko, 2009)

The developed product is stated to be worthy to be tested if the minimum level of validity that is achieved based on validator assessment results into the category is fair.

While the analysis of pretest and posttest to test product effectiveness used N-Gain score. N-Gain score is obtained from the following formula:

$$
(g)=\text { normalized gain }=\frac{\text { post test }- \text { pre test }}{\max \text { score }- \text { pre test }}
$$

The result of the gain calculation is then interpreted by using the classification as in Table 3 .

Table 3: Classification of Gain

\begin{tabular}{|l|l|}
\hline Normalized gain average & Classification \\
\hline$(g) \geq 0,70$ & High \\
\hline $0,30 \leq(g)>0,70$ & Medium \\
\hline$(g)<0,30$ & Low \\
\hline
\end{tabular}

(Meltzer, 2002)

\section{Results:-}

The main result of this research is the product of SW based on PBL to train students' critical thinking skill in works and energy materials.

The result of study found that $100 \%$ of teachers at the beginning of learning will explain an orientation in form of phenomena related to material taught to students, and it raises problems that would be solved by students. However $66.67 \%$ of teachers did not give students opportunity to provide temporary answers to problems that arose. So, in this case the method is still a teacher-center and it does not give an opportunity to students to be involved or active in learning process. $66.67 \%$ of teachers in lesson do not facilitate students to collect data and information to test the truth of temporary answer that has been proposed. In this case, there is no activity from students to solve problem independently.

From the results of field studies, teachers and students agree to have SW that can help students to be active in learning process and train students' critical thinking skills. SW that will be developed in accordance with the objective is SW based on PBL.Next is the planning stage, this stage is done by determining material and learning activities presented in SW, and determining content format and design display of developed SW. The result of the planning stage is determination of subject materials that will be presented in SW, is works and energy materials for SHS X class at Basic Competency 3.9 and 4.9. The sub-material chosen is kinetic energy and potential energy, works concept, the relationship between works and energy, and law of conservation of mechanical energy. Then, planning of SW content component consists of introductory, content, and closing parts.

The next activity is to determine the SW design format, is cover design and content design. The result of introduction of preliminary product done at this stage is prototype I. 
The next prototype I product is tested to determine the validity of content and validity of product constructs through expert test, before SW product is tested to students. Expert validitytest of SWprototype I is done by lecturer and practitioner using questionnaire. The results of expert validitytest of content and construct of the products that have been developed can be seen in Table 4.

Table 4: Experimental assessment test results

\begin{tabular}{|l|l|l|l|l|}
\hline No & Validator & Type of Test & Score & Qualitative statement \\
\hline 1 & Expert Lecturer 1 & Content validity & 76 & Excellent \\
& & Construct Validity & 56 & Excellent \\
\hline 2 & Expert Lecturer 2 & Content validity & 67 & Good \\
& & Construct Validity & 52 & Good \\
\hline 3 & Expert Practitioner & Content validity & 69 & Excellent \\
& & Construct Validity & 51 & Good \\
\hline
\end{tabular}

Based on expert test results, average content validity of 70.67 is obtained in excellent category, and average construct validity is 53 which is in good category. So that SW prototype I as a result of development has been feasible to be used as instructional material of learning. Experts also provide suggestions and feedback on SW that have been developed.The prototype I products that have been tested by experts are then refined based on inputs and suggestions from experts. SW product of improvement is called product of prototype II. Product prototype II is then field tested to the user.

The next stage is a one-on-one test conducted to determine legibility of product addressed to eight students as users. The result of product legibility test on the use of SW test one on one is 25.6 with qualitative statement is excellent. Based on the assessment on the one-to-one legibility test, it is known that language used in SW is easy to understand.

Teaching material in form of SW consists of 29 pages divided into three parts, namely introduction, content, and cover. Introduction contains front cover, introduction, table of contents, and content standards. The content consists of four sub-materials, namely kinetic energy and potential energy, works concept, relationship between works and energy, and law of conservation of mechanical energy. In each sub-chapter there are indicators and learning objectives. In addition, this teaching material is equipped with "let's explore" activities that can train students to develop their scientific attitude and critical thinking skills. The cover section contains a bibliography.

Presentation of material on SW based on PBL is that students are given problem orientation that challenges students to practice their critical thinking skills through simple experimental activities "let's explore". This teaching material has many illustrations. The goal is to make students understand the material easier. Based on a research by Cook (2008), illustration can be used as a tool to gain understanding of process or procedure, and accompanied by explanation in form of writing to improve it. Illustrations exist in teaching materials are in form of tables, graphics, and images.

Field test was conducted in X class MIA 7 one of State high school in Lampung Province as experiment class with 25 students. Learning process begins by explaining to students about physics learning process that will be done using SW on Works and Energy materials, then will be ended by students doing problem of critical thinking pretest. This pretest problem is intended to find out initial ability of critical thinking before the use SW. In the end of student learning will also be given posttest to know students' critical thinking skills achievement after the learning process using SW based on PBL is done.To know the increase of pretest and posttest score using n-gain test, and then statistical hypothesis test using paired sample t-test. The average score of n-gain test result in the experimental class and control class can be seen in Table 5 .

Table 5: N-gain test result score average

\begin{tabular}{|l|l|l|l|l|l|}
\hline & Pre Test & Post Test & Standard deviation & N-Gain & P \\
\hline Eksperiment Class & 43,9 & 77,8 & 4,827 & 0,6 & $0,000^{*}$ \\
\hline Control Class & 39,2 & 57,2 & 3,485 & 0,31 & $0,000^{*}$ \\
\hline
\end{tabular}

significantlydifferenceat the level of $5 \%$ 
Based on the table above, it can be seen that the results obtained n-gain in the experimental class of 0.6 , so it can be concluded that students' critical thinking skills improvement is in medium criteria. This is in accordance with the results of Redhana\&Sudiatmika (2009) study which states that the development of learning tools based on PBL can improve students' critical thinking skills.

To know the increase of pretest score with posttest in experiment class can also use hypothesis test. The result of statistical hypothesis test using paired sample t-test obtained p score $0.000<0,05$, it can be concluded that posttest score after using product developed significantly higher than pretest score before using developed product.

To know the difference of posttest score average in experiment class and control class, it is done by statistical hypothesis test using Independent Sample T-Test. The result of statistical hypothesis test using Independent Sample T-Test $\mathrm{p}$ score $0.000<0,005$, it can be concluded that there is a difference between posttest score average in experiment class and in control class, or posttest score average of the experimental class using the developed product is significantly higher than post test score average of control class that does not use the developed product. Improvement of critical thinking skills based on indicators on the experimental and control class can be seen in Table 6.

Table 6: Calculation resultof critical thinking indicator improvement

\begin{tabular}{|l|l|l|l|l|l|l|l|l|}
\hline \multirow{2}{*}{ No } & \multirow{2}{*}{ Critical Thinking Indicators } & \multicolumn{3}{|c|}{ Experiment Class } & \multicolumn{3}{|c|}{ Control Class } & P \\
\cline { 3 - 9 } & & Pre-test & Post-test & N-gain & Pre-test & Post-test & N-gain & \\
\hline 1 & Providing a simple explanation & 45,2 & 78,4 & 0,62 & 34 & 55,2 & 0,32 & $0,000^{*}$ \\
\hline 2 & Building basic skills & 48 & 75,6 & 0,57 & 47,2 & 64,4 & 0,34 & $0,000^{*}$ \\
\hline 3 & Summarizing & 43,24 & 73,88 & 0,55 & 38 & 57 & 0,3 & $0,000^{*}$ \\
\hline 4 & Making further explanation & 36,8 & 77,6 & 0,67 & 44 & 58,4 & 0,25 & $0,000^{*}$ \\
\hline 5 & Setting strategies and tactics & 42,4 & 92,8 & 0,89 & 44 & 64 & 0,31 & $0,000^{*}$ \\
\hline
\end{tabular}

significantlydifferenceat the level of $5 \%$

Based on table 6, it is known that all indicators of critical thinking skills in the experimental class experience improvement after using SW developed in the learning process. The indicators provide a simple explanation, build basic skills, conclude, make further explanations, and set strategies and tactics into the medium category. While in control class, the indicators provide simple explanations, build basic skills, summarize, make further explanations, and set strategies and tactics into the medium category.

From N-gain calculation results of critical thinking indicator achievement, it can be seen that the highest indicator that increase in experimental class are indicators to make further explanation and set the strategy and tactics.

After field trial, final product of this research is obtained. The final product of development is SW based on PBL to train students' critical thinking skill.

\section{Discussion:-}

The development is done to produce SW based on SW to train students' critical thinking skills on works and energy material as one of teaching materials that can be used by students and teachers in teaching and learning activities. $\mathrm{SW}$ is developed in printed form.

The developed SW has been validated in terms of content, construct, and legibility. Validity in terms of content obtained score of 70.67 with percentage $88.34 \%$, and in terms of design obtained score of 53 with $81.53 \%$ percentage. Result of legibility test obtained score 25.6 with percentage $85.33 \%$. Based on that, it is known that the developed product is suitable to be used in learning process.

Next is user response to the product that is being developed. User responses are addressed to students and teachers. Teacher response result of 101 is in excellent category, and result of student response equal to 80,72 is in good category. Thus, it shows that SW based on PBL is effectively used in learning process. This is consistent with Swan's research, et al (2013) suggesting this PBL approach can be implemented effectively across the study field. Ward \& Lee (2002) reveal the basic concept of PBL is that students will learn the material effectively by trying to solve real problems. 
Based on the results of assessment shown in Figure 1, students' initial critical thinking skillis in medium category and almost n-gain low. This indicates that students' critical thinking skills were still poorly trained before. This is because students were not used to generate many ideas for questions and perform detailed steps. However, after treatment using developed products, students' critical thinking skills have increased, it is in the medium category with a greater n-gain score.

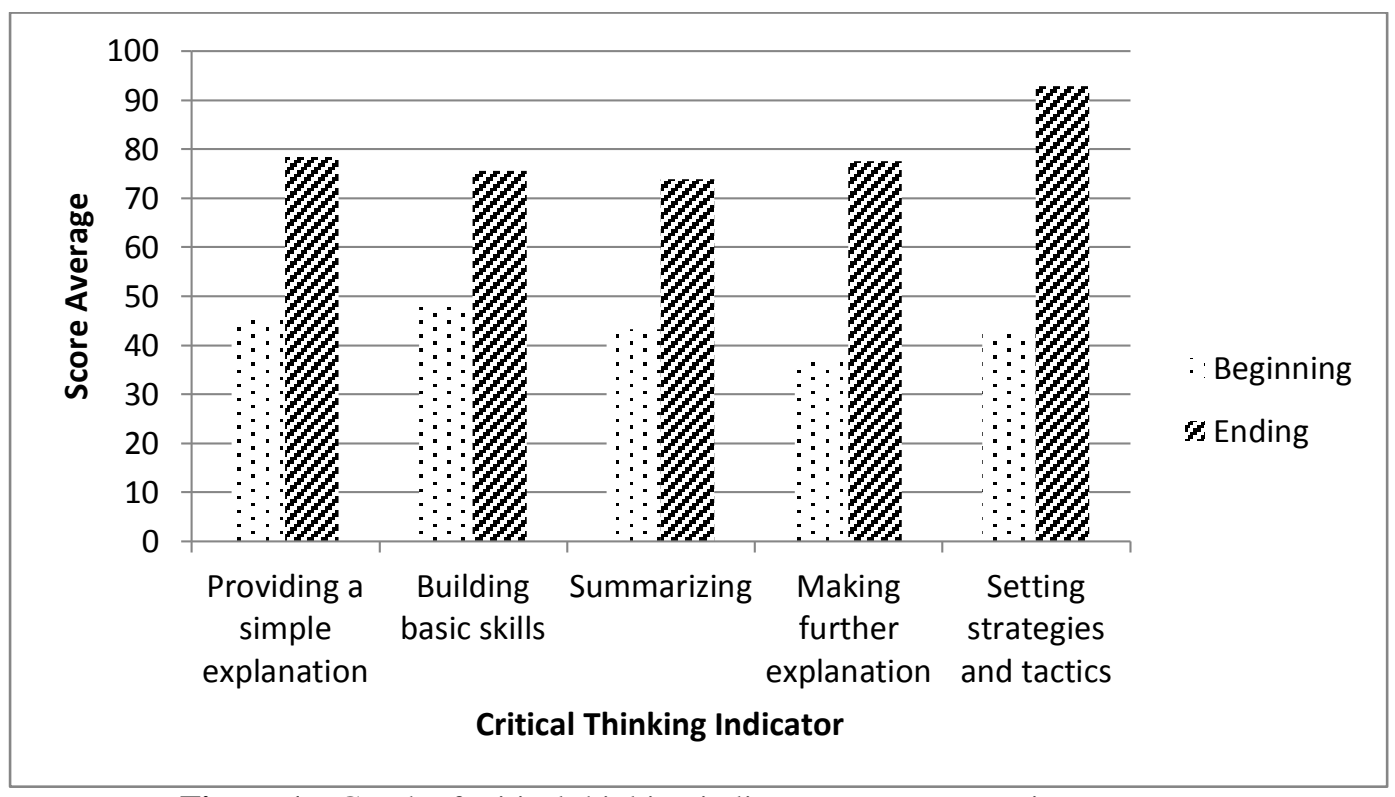

Figure 1:- Graph of critical thinking indicator average score improvement

Treatment activities using developed product, students are taught to explore data through exploration activities and through detailed and systematic steps so that students can answer various questions, there by all indicators of critical thinking like providing a simple explanation, building basic skills, summarizing, making further explanations, and setting strategies and tactics improve.

The result of research shows that there is an overall improvement of students' critical thinking skill test between pretest and posttest, which is difference of test result of student before and after applying learning with developed SW based on PBL. Result of pretest of students' critical thinking indicator get average score 43.13. Then, posttest get average score 79.66. Based on analysis of the increase of average score of pretest and posttest after applied learning using SW based on PBL calculated by using N-gain formula got score increase 0,66 which mean increase of average score of pretest and posttest are in medium category. This is in accordance with the results of research conducted by Eldy, et al (2013) which states that learning with PBL can improve students' critical thinking skills.

Increased test results about critical thinking because of learning using PBL based SW. The developed SW presents students with problem orientations that can provide an opportunity for students to conduct investigations through "let's explore" activities. The developed SW contains a learning model designed to train students' critical thinking skills. The results achieved in this study are in accordance with the findings of Crhristiana\&Suniasih (2014) which states that the PBL model influences students' critical thinking skills. This shows that learning process using SW based on PBL is effectively applied to train students' critical thinking ability. The PBL model demands students to be actively participating in learning, besides PBL also facilitates students to collaborate with other students in solving the problems presented.

\section{Conclusion:-}

Based on discussion above, conclusion in this study (1) SW based on PBL can train students' critical thinking skills on works and energy materials starting form problem orientation along with illustrations that elicit challenging questions and require critical thinking skills to solve problem. (2) SW that have been developed effectively train students 'critical thinking skills seen from improving students' thinking skill on each indicator. SW has been effectively used in the learning process seen from the average score of $\mathrm{N}$-gain of 0.6 in medium category, and hypothesis test results that there is a difference between the average score in the experimental class with the score in 
the control class, (3) Student and teacher response to SW are also well. Teacher response results is in excellent category and student response results is in good category. Through this SW based PBL, students feel the difference in an interesting learning atmosphere and then more involving the active role of students in learning process can also provide a new learning experience for students.

\section{Reference:-}

1. Christiana, P.P., Suniasih, N. W., \& Suadnyana, I. N. 2014. The Influence of Problem Based Learning Model Based on the Critical Thinking Skills of SD SDU Gugus VIII Sukawati. e-Journal Mimbar PGSD Universitas Pendidikan Ganesha; 2(1): 183-192.

2. Cook, M. 2008. Student's Comprehension of Science Concepts Depicted in Textbook Illustrations. Electronic Journal of Science Education; 12(1): 2-14.

3. Eldy, E. F. \& F. Sulaiman. 2013. The Capability of Integrated Problem Based Learning Improving Students' Level of Creative-Crtical Thinking. International Journal of e-Education, e-Business, e-Management, and eLearning; 3(4): 347-350.

4. Fitriani, W., Bakri, F., \& Sunaryo, S. 2017.The Development of Physics Students Workbook (LKS) to Train High Order Thinking Skill (High Order Thinking Skill) of High School Students. Wahana Pendidikan Fisika; 2(1): 36-42.

5. Gall, M. D., Gall, J. P., Borg, W. R. 2003. Educational Research. New York: Allyn and Bacon.

6. Haryati, M. 2007. Models and Assessment Techniques at Education Unit Level. Jakarta: Gaung Persada Press.

7. Lee, C. D. 2014. Workbook usage, reading achievement, classes' lack of readiness and science achievement: A cross-country comparison. International Journal of Education in Mathematics, Science and Technology; 2(2): 96-106.

8. Lien, P.C. 2009. Learning from problem-based learning in a web-based environment: a systematic review. Reflection on $P B ; 2(9)$ : 12-17.

9. Meltzer, D. E. 2002. The Relationship Between Mathematics Preparation and Conceptual Learning Gain in Physics: A Possible Hidden Variable in Diagnostic Pretest Scores. American Journal Physics; 70(2): 12591267.

10. Minister of Education and Culture RI Number 69 of 2013.Regulation Attachment of Indonesian Minister of Education and Culture Number 69 of 2013 on High School Curriculum Structure. Jakarta: Minister of Education and Culture.

11. Raimi, S.M. \& Adeoye, F.A. 2012. Problem Based Learning Strategy and Quantitative Ability in College of Education Student's Learning of Integrated Science.Ilorin Journal of Education; 5(1): 1-11.

12. Redhana, I. W., Sudiatmika, A. A. I. A. R., \& Artawan, I. K. 2009. The Development of Problem Based Learning Tools and Socratic Questions to Improve the Critical Thinking Skills of Junior High School Students. JPP Undiskha; 42(3): 153-159.

13. Sari. 2012. The Implementation of Problem Based Learning Model (PBL) to Improve the Critical Thinking Ability of Students on Science Lesson Grade VIII SMP N 5 Sleman. Yogyakarta:FMIPA UNY.

14. Swan, K., Vahey, P., Hooft, M.V., Kratcoski, A., \& Rafanan, K. 2013. Problem-based learning across the curriculum: exploring the efficacy of a crosscurricular application of preparation for future learning. InternationalJournal of Engineering Education; 7(1): 91-110.

15. Ward, J.D. \& Lee, C.L. 2002. A Review of Problem-Based Learning.Journal of Family and Consumer Sciences Education; 1(20): 16-26.

16. Widoyoko, E. P. 2009. Learning Program Evaluation. Yogyakarta: Pustaka Pelajar. 